\title{
Papiamento Language
}

National Cancer Institute

\section{Source}

National Cancer Institute. Papiamento Language. NCI Thesaurus. Code C154076.

A Portuguese-based creole language spoken in the Dutch West Indies. 